\title{
Anti-malarial activity of the root extract of Euphorbia abyssinica (Euphorbiaceae) against Plasmodium berghei infection in mice
}

\author{
Abrham Belachew Muluye ${ }^{1 *}\left(\mathbb{D}\right.$, Ashenafi Genanew Desta', Selamu Kebamo Abate $^{2}$ \\ and Gemechu Tiruneh Dano ${ }^{3}$
}

\begin{abstract}
Background: More than 200 medicinal plants including Euphorbia abyssinica are utilized for treatment of malaria in Ethiopian traditional medical practices. However, the safety, efficacy and quality of these medicinal plants are largely unknown. Pharmacological and toxicological investigations of these plants are among the prioritized issues in every country. The aim of this study was, therefore, to evaluate the anti-malarial activity of Euphorbia abyssinica root extract against Plasmodium berghei infection in mice.

Methods: The fresh roots of Euphorbia abyssinica were identified and collected. They were dried and extracted by $80 \%$ methanol using maceration. Acute toxicity of the extract was done using female Swiss albino mice. Anti-malarial activity of the extract was done by a standard 4-day suppressive test using chloroquine-sensitive Plasmodium berghei. Twenty-five male Swiss albino mice were randomly grouped into 5 groups of 5 mice each. Group I was treated with distilled water (10 ml/kg), group II, III, and IV were treated with 200, 400, and $600 \mathrm{mg} / \mathrm{kg}$ of extract, respectively and group $\vee$ was treated with chloroquine $(25 \mathrm{mg} / \mathrm{kg})$. The level of parasitaemia, survival time, and variation in weight were utilized to determine the anti-malarial activity of the extract. Data was analysed using ANOVA followed by Tukey test.
\end{abstract}

Results: The plant extract did not show any sign of toxicity and mortality at $2000 \mathrm{mg} / \mathrm{kg}$. The 4-day chemosuppressive anti-malarial activities produced by the crude extract were 66.87\% $(P<0.001), 84.94 \%(P<0.001)$ and $93.69 \%$ $(P<0.001)$ at 200, 400 and $600 \mathrm{mg} / \mathrm{kg}$ extract, respectively, compared to distilled water treated group. Mice treated with $400 \mathrm{mg} / \mathrm{kg}(\mathrm{P}<0.01)$, and $600 \mathrm{mg} / \mathrm{kg}$ extract $(\mathrm{P}<0.001)$ showed significant chemosuppressive anti-malarial activity variations as compared to mice treated with $200 \mathrm{mg} / \mathrm{kg}$ extract. Mice treated with $600 \mathrm{mg} / \mathrm{kg}$ extract significantly $(P<0.001)$ lived longer than distilled water treated mice. However, the crude extract did not cause any significant change on body weights of mice.

Conclusions: From this study, it can be concluded that the root of Euphorbia abyssinica showed very good 4-day chemosuppressive anti-malarial activity. The plant might contain biologically active compounds which are relevant for treatment of malaria. Further phytochemical, toxicological and pharmacological investigations are, therefore, required to evaluate its anti-malarial potential.

Keywords: Anti-malarial activity, Euphorbia abyssinica, Malaria, Mice, Plasmodium berghei

\footnotetext{
*Correspondence: abrhambel@gmail.com

${ }^{1}$ Department of Pharmacy, College of Medicine and Health Sciences,

Bahir Dar University, Bahir Dar, Ethiopia

Full list of author information is available at the end of the article
} 


\section{Background}

Infectious diseases have a significant burden on global public health and economic stability. Malaria is one of the deadliest infectious diseases worldwide and the biggest health threats in Africa [1, 2]. According to the World Health Organization (WHO), about $54 \%$ and $90 \%$ of the world's and African population are at risk of malaria, respectively. In 2017, an estimated 219 million malaria cases which caused 435,000 global deaths were reported by the WHO. Most of these cases (92\%) and deaths (93\%) were in Africa. Pregnant women and children under 5 years were the most vulnerable groups [3].

The emergence and spread of resistances of mosquitoes to existing insecticides and parasites to current effective anti-malarial drugs $[4,5]$, development of new antimalarial drug pipelines remain sadly thin with very little chemical diversity [6], logistical problems of anti-malarial drugs in poorest malaria-endemic countries $[7,8]$, and lack of safe and effective anti-malarial vaccines [9] might increase the complication and resurgence of malaria in the future. As these complicating factors continue to increase, there is a great concern that malaria may continue to present a formidable challenge on the current progress made on its control and the global goal of its elimination and eradication [1]. Effective, safe, affordable and accessible alternative new anti-malarial agents and strategies are, therefore, urgently needed $[10,11]$.

Nearly $80 \%$ of the world's population especially in developing countries like Ethiopia used plant-derived drugs to meet their primary healthcare demands [12]. From 14 to $28 \%$ of higher plant species are used for treatment and prevention of various health ailments in different traditional medical practices. A total of 45,000 and 7000 plant species are estimated in Africa and Ethiopia, respectively [13]. Twelve percent of Ethiopia's floras are considered to be endemic [14, 15]. More than 1277 and 200 higher plant species are utilized for treatment and/or prevention of malaria and malarial fever in the world and in Ethiopian traditional medical practices, respectively [9, 16].

Medicinal plants of both endemic and widespread are the renewable sources for new drugs [17]. Anti-malarial drug discovery especially from plants is currently more targeted because histories proved that plants are the richest sources of effective and safe anti-malarial phytochemicals [11]. As they are many in number and contain molecules with a great variety in structure and biological activity, medicinal plants have made and continue to make a great contribution to anti-malarial drug discovery and development. However, only a limited number of medicinal plants used in traditional medical practices are investigated for their phytochemical profile, toxicological, and pharmacological activities $[18,19]$.
Euphorbia abyssinica belongs to Euphorbiaceae, which comprises about 300 genera and 8000 plant species. Euphorbia consists of more than 2000 plant species occurring in all temperate and tropical regions [20,21]. Euphorbia abyssinica is a succulent, spiny tree, towering up to $10 \mathrm{~m}$ in height. It either stands large or grows as solitary plant in moist montane forest, humid woodlands and scrub savannah. The plant is endemic to Eastern Africa including Ethiopia, Eritrea, Somalia, and Sudan. It grows at an altitude of 1400 to 2400 metres. It has a toxic milky sap. If the sap exposed to body, it caused rash, irritant dermatitis and blistering, irritant keratoconjunctivitis, blindness, nausea and vomiting. Many plants in the family of Euphorbiaceae contain euphorbon (a dangerous poison) [22, 23].

Euphorbia abyssinica is used for live fencing, firewood, and timber. There is no ethnobotanical data on the use of Euphorbia abyssinica as a traditional medicinal plant outside Ethiopia. It is rather classified as a poisonous plant by the Food and Drug Administration of the United States of America [24]. In Ethiopian traditional medical practices, the plant has been utilized for treatment of various diseases including malaria [25-31]. Its medicinal effects are mainly confined to its latex and roots $[14,22]$. The mode of preparation of the plant for treatment of malaria by local people and/or herbalists was as followed: the fresh root was collected; it was chopped using stone and woody materials; the chopped plant material was dried under sunlight; the dried product was further powdered and eaten with egg then a lot of milk was drunk.

However, the safety, quality and efficacy of Euphorbia abyssinica for treatment of malaria have not been verified scientifically. There are reports on the anti-malarial activities of two other related species namely Euphorbia hirta [32] and Euphorbia prostrata [33]. It is justifiable to scientifically evaluate its anti-malarial activity in rodent malarial model to support or deject its folk use in the treatment of malaria. This study was, therefore, designed to evaluate the anti-malarial activity of $80 \%$ methanolic root extract of Euphorbia abyssinica against Plasmodium berghei infection in mice.

\section{Methods}

\section{Collection and preparation of the plant material}

The fresh roots of $E$. abyssinica were collected in Nekemte town, East Wollega zone, Western Ethiopia in March 2018. The plant was identified and authenticated by botanists in Department of Biology, Wollega University, Ethiopia. A voucher specimen was deposited at National Herbarium, Addis Ababa University, Ethiopia. The collected roots were cleaned, washed, and air dried under shade at room temperature. The dried roots were coarsely powdered. Then the powdered plant materials 
were stored in a plastic container and they were kept at room temperature until extraction.

\section{Extraction of the plant materials}

The powdered samples of roots of Euphorbia abyssinica (355 g) were weighed by sensitive electrical balance (Adam equipment, France). They were extracted by maceration with $80 \%$ methanol (Okhla Industrial, India) for three consecutive days with orbital shaker (Lab Teck, India) in Chemistry Laboratory of Department of Chemistry, Wollega University. After 3 days, the mixture was filtered with Whatman filter paper number one (Whatman, England). The residue was re-macerated twice for the same duration of days and then the mixture was filtered. The combined filtrates were dried by rota evaporator (Rotovap, India) and hot oven (250 V, France). The weight of the dried extract was measured to determine the percentage yield. The dried extract was kept in a fridge until experiment.

\section{Experimental animals}

Twenty-five male Swiss albino mice inbred in the Animal House of Ethiopian Public Health Institute were used for anti-malarial activity testing. Five female Swiss albino mice were used for acute toxicity study. They were housed in plastic cages with softwood shavings and chips as beddings. They had free access to pellet diet and clean drinking water. All animals were acclimatized to the working environment 1 week before the beginning of the experiment.

\section{Parasites}

Chloroquine-sensitive Plasmodium berghei (ANKA strain) was used for induction of malaria in experimental mice. Mice previously infected with $P$. berghei were used as donor. The donor $P$. berghei infected mice were obtained from Traditional Medicine Department of Ethiopian Public Health Institute. The parasites were subsequently maintained in laboratory by serial passage of blood from donor infected mice to naive one via intraperitoneal route on weekly basis.

\section{Study design and sampling method}

Experimental study design was used. Simple random sampling technique was employed for grouping of experimental animals and assignments of treatments.

\section{Inoculum preparation}

The parasitaemia of the previously $P$. berghei infected donor mouse was determined. The blood from these mice was collected via cardiac puncture with a parasitaemia of $35 \%$ into a test tube having $0.5 \%$ trisodium citrate. The blood was then diluted with normal saline to give $2 \times 10^{7}$ infected red blood cells (RBCs) in an injection volume of $0.2 \mathrm{ml}$. Each mouse was then infected by injecting $0.2 \mathrm{ml}$ of this diluted blood via intra-peritoneal route which contained $2 \times 10^{7}$ infected RBCs [34].

\section{Grouping and dosing of animals}

Twenty-five mice were grouped into five groups of five mice each. Group I mice was treated with the vehicle (distilled water, $10 \mathrm{ml} / \mathrm{kg}$, which served as negative control), group II, III and IV mice were treated with 200, 400, and $600 \mathrm{mg} / \mathrm{kg}$ of crude extract, respectively and the last group (group V) mice was treated with the standard drug [chloroquine (Addis Pharmaceuticals Factory, Ethiopia), $25 \mathrm{mg} / \mathrm{kg}$, which served as positive control]. Since patients used the plant traditionally for treatment of malaria orally, all treatments were administered to mice via intra-gastric route using oral gavage for safe ingestion.

\section{In vivo acute toxicity test}

Acute toxicity test of the extract was conducted in five nulliparous, non-pregnant female Swiss albino mice from 8 to 12 weeks old. They were fasted from food overnight. They were dosed sequentially with the extract at a limit dose of $2000 \mathrm{mg} / \mathrm{kg}$. If the first animal was survived, the four additional animals were dosed sequentially so that a total of five animals were tested. Accordingly, mice were observed for any sign of gross physical and behavioural changes over an hour, $4 \mathrm{~h}, 24 \mathrm{~h}$, and for 14 days. If three or more animals were survived, the median lethal dose $\left(\mathrm{LD}_{50}\right)$ will be greater than the test dose. At the end, surviving animals were humanely killed. The test procedure was done according to Organization for Economic Cooperation and Development (OECD) guideline [35].

\section{Four-day chemosuppressive anti-malarial activity test}

The chemosuppressive test was done by using a standard 4-day suppressive test against $P$. berghei infection in mice as described by Fidock et al. [36]. After standard parasite inoculation, 25 mice were randomly divided into five groups of five mice each. Treatments were started $3 \mathrm{~h}$ after infection for each group accordingly and then continued for three consecutive days (from $\mathrm{D}_{0}$ to $\mathrm{D}_{3}$ ). On the fifth day $\left(D_{4}\right)$, thin blood films were made from the tail of each mouse on a microscopic slide (Sciencelab, USA).

\section{Peripheral blood smear preparation}

Thin blood smears were made from the tail of each mouse on the fifth day $\left(D_{4}\right)$. The smears were applied on microscopic slides and the blood was drawn evenly across a second slide to make a thin blood film and allowed to dry at room temperature. They were fixed with absolute methanol and stained with 10\% Giemsa stain (Macsenlab, India) 
at $\mathrm{pH} 7.2$ for $15 \mathrm{~min}$. Each stained slide for each mouse was examined under microscope (Olympus, Japan).

\section{Parasitaemia determination}

The parasitaemia level was determined by counting the number of parasitized RBCs in random fields of the microscope. The smears were read and counted by a laboratory technician to make the reader blind to the category. Average parasitaemia and percent parasitaemia suppression were calculated using the following formula [36].

$$
\% \text { Parasitaemia }=\frac{\text { Number of Infected RBCs }}{\text { Total Number of RBCs }} \times 100
$$

$$
\begin{aligned}
& \text { \% Suppression } \\
& =\frac{(\text { Mean Parasitaemia of NC }- \text { Mean Parasitaemia of TG })}{\text { Mean Parasitaemia of NC }} \\
& \times 100
\end{aligned}
$$

where $\mathrm{NC}$, negative control; TG, treated group.

\section{Determination of mean survival times}

Mean survival time (MST) is another parameter that is commonly used to evaluate the efficacy of anti-malarial plant extracts. An extract that results in survival time greater than that of infected non-treated mice was considered as active. Death occurring before day 5 of infected and treated mice was regarded as toxic death. Mortality was monitored daily. The number of the days from the time of inoculation of the parasite up to death was recorded for each mouse in the treatment and control groups throughout the follow up period. The survival time for each mouse was recorded after the treatment periods.

$$
\text { MST }=\frac{\text { Sum of Survival Time of All Mice in a Group (days) }}{\text { Total Number of Mice in That Group }}
$$

\section{Body weight determination}

Similarly, body weight loss is one feature of rodent malaria infections. Body weight of each mouse was measured to determine the effectiveness of the extract. The body weight of each mouse in all groups was taken before infection $\left(D_{0}\right)$ and after treatment $\left(D_{4}\right)$. The weight of each mouse was measured using sensitive electrical balance. The average body weight changes of extract treated groups were compared with the control groups. The average body weight change of each treatment group was calculated using the following formula.

Average Weight Change $=$ Average $\mathrm{D}_{4}$ Weight of a Group - Average $\mathrm{D}_{0}$ Weight of that Group

\section{Statistical analysis}

Results of the study were expressed as mean \pm SEM (standard error of mean) for each treatment group. Data on levels of parasitaemia, changes in body weights and survival times were analysed using windows SPSS version 20. One-way ANOVA was used to analyse differences among groups. Subgroup analysis was done using Tukey post hoc test. The difference was considered statistically significant if P-value $<0.05$.

\section{Data quality control}

Randomization was used during grouping of experimental animals and assignments of treatments. Codes were utilized for all microscopic slides. Parasitized RBCs were counted blindly by a laboratory technician.

\section{Ethical consideration}

Ethical clearance was requested and approved by the ethical committee of College of Health Sciences, Wollega University, Ethiopia. During experimental procedures, experimental animals were handled and cared according to the internationally accepted laboratory animals' use, care and welfare guideline [37].

\section{Results}

\section{Percentage yield of the crude plant extract}

The percentage yield of $80 \%$ methanolic crude extract of the roots of Euphorbia abyssinica was $7.04 \%$ weight by weight. Its actual yield was $25 \mathrm{~g}$. The dry extract was dark red and hygroscopic.

\section{In vivo acute toxicity of the crude plant extract}

All mice tested at the limit dose of $2000 \mathrm{mg} / \mathrm{kg}$ were normal during the observation periods. Gross physical and behavioural changes including rigidity, sleep, diarrhoea, depression, abnormal secretion and hair erection were not observed within $24 \mathrm{~h}$. There were no deaths occurred within 14 days. The $\mathrm{LD}_{50}$ might be greater than the limit dose. The mice were humanly killed after the observation periods. This safety data was used for selection of the three dose levels (200, 400 and $600 \mathrm{mg} / \mathrm{kg}$ ) of the crude root extract of Euphorbia abyssinica for the anti-malarial activity evaluation in mice.

\section{Four-day chemosuppressive anti-malarial activity of the crude plant extract}

The 80\% methanolic crude extract of the roots of Euphorbia abyssinica showed significant chemosuppressive antimalarial activity against $P$. berghei infection in mice. Mice treated with 200,400 and $600 \mathrm{mg} / \mathrm{kg}$ extract showed $66.87 \%, 84.94 \%$ and $93.69 \%$ chemosuppressive antimalarial activities, respectively, as compared to distilled water treated mice. Similarly, 400 and $600 \mathrm{mg} / \mathrm{kg}$ extract treated mice showed significant chemosuppressive antimalarial activity variations as compared to $200 \mathrm{mg} / \mathrm{kg}$ extract treated mice as shown in Table 1. 
Effect of crude plant extract on survival times of mice Distilled water treated mice died within a week of infection while chloroquine-treated group survived and were cured. Mice treated with $600 \mathrm{mg} / \mathrm{kg}$ extract significantly survived longer than the corresponding distilled water treated mice $(\mathrm{P}<0.001)$ and $200 \mathrm{mg} / \mathrm{kg}$ extract treated mice $(\mathrm{P}<0.05)$ as shown in Table 2.

\section{Effect of crude extract on body weights of mice}

Although the differences were not statistically significant, all extract treated mice prevented body weight loss as compared to distilled water treated mice. There were no significant differences among the body weight gains of extract treated groups. Chloroquine-treated mice did not lose weight as shown in Table 3.

\section{Discussion}

More than $80 \%$ of African population such as Ethiopian's used plant-derived drugs to meet their primary healthcare demands. Three-fourth of Ethiopian lands is malarious and $68 \%$ population lived in such malaria risky areas. Ethiopia is among the malaria endemic and poorest country in the world. Because of cultural entrenchment, cheapness and easily accessibility, medicinal plants are the main sources of drug for different health ailments including malaria in Ethiopian traditional medical practices. More than 200 medicinal plants are currently utilized for treatment of malaria in Ethiopia. However, the safety, quality and efficacy of these medicinal plants are largely unknown. Assessments of these qualities of medicinal plants are among the prioritized issues in the country [38-41].

Rodent malaria model in mice is the most extensively used for the primary in vivo investigation of natural and

Table 1 Four-day chemosuppressive anti-malarial activity of $80 \%$ methanolic crude extract of the roots of Euphorbia abyssinica against Plasmodium berghei infection in mice

\begin{tabular}{llll}
\hline Treatments & Doses & $\begin{array}{l}\text { Parasitaemia } \\
\text { (\%) }\end{array}$ & $\begin{array}{l}\text { Chemosuppression } \\
\text { (\%) }\end{array}$ \\
\hline Distilled water & $10 \mathrm{ml} / \mathrm{kg}$ & $24.90 \pm 1.54$ & 0.00 \\
$\begin{array}{l}\text { Euphorbia abys- } \\
\text { sinica crude }\end{array}$ & $200 \mathrm{mg} / \mathrm{kg}$ & $8.25 \pm 0.56$ & $66.87^{\mathrm{a} 1, \mathrm{c} 2, \mathrm{~d} 1, \mathrm{e} 1}$ \\
root extract & $400 \mathrm{mg} / \mathrm{kg}$ & $3.75 \pm 0.75$ & $84.94^{\mathrm{a} 1, \mathrm{~b} 2, \mathrm{e} 3}$ \\
Chloroquine & $600 \mathrm{mg} / \mathrm{kg}$ & $1.57 \pm 0.49$ & $93.69^{\mathrm{a} 1, \mathrm{~b} 1}$ \\
\hline
\end{tabular}

Values are expressed as mean $\pm S E M ; n=5$

${ }^{1} \mathrm{P}<0.001 ;{ }^{2} \mathrm{P}<0.01 ;{ }^{3} \mathrm{P}<0.05$

a As compared to negative control

b As compared to $200 \mathrm{mg} / \mathrm{kg}$ extract

c As compared to $400 \mathrm{mg} / \mathrm{kg}$ extract

d As compared to $600 \mathrm{mg} / \mathrm{kg}$ extract

e As compared to positive control
Table 2 Effect of $80 \%$ methanolic crude extract of the roots of Euphorbia abyssinica on the mean survival times of Plasmodium berghei infected mice

\begin{tabular}{lll}
\hline Treatments & Doses & Mean survival times (days) \\
\hline Distilled water & $10 \mathrm{ml} / \mathrm{kg}$ & $7.40 \pm 0.51$ \\
Euphorbia abyssinica & $200 \mathrm{mg} / \mathrm{kg}$ & $9.00 \pm 0.71^{\mathrm{d} 2, \mathrm{e} 1}$ \\
crude root extract & $400 \mathrm{mg} / \mathrm{kg}$ & $9.80 \pm 0.80^{\mathrm{e} 1}$ \\
& $600 \mathrm{mg} / \mathrm{kg}$ & $12.00 \pm 0.71^{\mathrm{a} 1, \mathrm{~b} 2, \mathrm{e} 2}$ \\
Chloroquine & $25 \mathrm{mg} / \mathrm{kg}$ & $15.00 \pm 0.00^{\mathrm{a} 1, \mathrm{~b} 1, \mathrm{c} 1, \mathrm{~d} 2}$ \\
\hline
\end{tabular}

Values are expressed as mean $\pm S E M ; n=5$

${ }^{1} \mathrm{P}<0.001 ;{ }^{2} \mathrm{P}<0.05$

a As compared to negative control

b As compared to $200 \mathrm{mg} / \mathrm{kg}$ extract

c As compared to $400 \mathrm{mg} / \mathrm{kg}$ extract

d As compared to $600 \mathrm{mg} / \mathrm{kg}$ extract

e As compared to positive control

Table 3 Effect of $80 \%$ methanolic crude extract of the roots of Euphorbia abyssinica on the body weights of Plasmodium berghei infected mice

\begin{tabular}{lllll}
\hline Treatments & Doses & \multicolumn{2}{l}{ Body weight (g) } \\
\cline { 3 - 5 } & & $\mathbf{D}_{\mathbf{0}}$-weight & $\mathbf{D}_{\mathbf{4}}$-weight & $\begin{array}{c}\text { Weight } \\
\text { change }\end{array}$ \\
\hline Distilled water & $10 \mathrm{ml} / \mathrm{kg}$ & $40.00 \pm 2.64$ & $36.34 \pm 2.40$ & -3.66 \\
Euphorbia abys- & $200 \mathrm{mg} / \mathrm{kg}$ & $37.72 \pm 0.78$ & $34.30 \pm 1.70$ & $-3.42^{\mathrm{cl}}$ \\
sinica crude & $400 \mathrm{mg} / \mathrm{kg}$ & $43.76 \pm 1.83$ & $42.78 \pm 1.87$ & -0.98 \\
root extract & $600 \mathrm{mg} / \mathrm{kg}$ & $41.92 \pm 1.07$ & $40.40 \pm 1.17$ & -1.52 \\
Chloroquine & $25 \mathrm{mg} / \mathrm{kg}$ & $40.26 \pm 0.80$ & $41.38 \pm 0.87$ & $1.12^{\mathrm{a} 1, \mathrm{~b} 1}$
\end{tabular}

Values are expressed as mean $\pm S E M ; n=5$

$1 \mathrm{P}<0.01$

a As compared to negative control

b As compared to $200 \mathrm{mg} / \mathrm{kg}$ extract

c As compared to positive control

synthetic anti-malarial agents. This model can detect prodrugs that require metabolic reactivation and the effect of agents on immune systems. The 4-day chemosuppressive model is the most widely used model for preliminary assessment of new anti-malarial agents [42].

All Euphorbia abyssinica extract treated mice showed significant chemosuppressive anti-malarial activities $(\mathrm{P}<0.001)$ as compared to distilled water treated mice in a dose-dependent manner. Mice treated with 400 and $600 \mathrm{mg} / \mathrm{kg}$ extract had significant chemosuppressive anti-malarial activities $(\mathrm{P}<0.01$ and $\mathrm{P}<0.001$, respectively) as compared to $200 \mathrm{mg} / \mathrm{kg}$ extract treated mice. A new anti-malarial compound is considered active when it causes parasitaemia suppression 30\% or more [42]. This supports the anti-malarial activity 
of the current plant material. Similar dose-dependent anti-malarial activities were reported by many plant extracts including Brassica nigra [43] and Indigofera spicata [44] in Ethiopia.

The current findings were further supported by the positive anti-malarial activities of two closely related plant species, namely Euphorbia hirta [32] and Euphorbia prostrate [33]. The crude methanolic root extract of the current plant $(200,400,600 \mathrm{mg} / \mathrm{kg})$ showed very significant $(\mathrm{P}<0.001)$ chemosuppressive anti-malarial activities of $66.87 \%$ to $93.69 \%$ while the crude ethanol extract of Euphorbia hirta whole plant (200, 400 and $800 \mathrm{mg} / \mathrm{kg})$ showed significant $(\mathrm{P}<0.05)$ chemosuppressive anti-malarial activity of $51 \%$ to $59 \%$, respectively against $P$. berghei infection in mice when compared to vehicle treated mice. Both Euphorbia hirta and Euphorbia prostrata had significant in vitro anti-plasmodial activities against $P$. falciparum. The current anti-malarial activity of the plant could be shared with the other pharmacological activities including acaricides and tick repellant [45], worm expelling [46], antibacterial [21, 47], antifungal [47], and wound healing [46, 48] activities of the plant. According to classification of new in vivo antimalarial activity of plant extracts [49], the methanolic crude extract of roots of Euphorbia abyssinica showed very good 4-day chemosuppressive anti-malarial activity.

Survival time is another parameter that evaluates the anti-malarial activity of plant extracts. An extract that resulted in survival time greater than that of infected non-treated mice was considered as active $[36,42]$. Mice treated with $600 \mathrm{mg} / \mathrm{kg}$ of extract significantly survived longer than distilled water treated mice. This might explain the anti-malarial activity of the plant extract. However, the mean survival times of extract treated mice were shorter than chloroquine-treated ones. This might be the fast reversible action or rapid elimination phase of the extract. This was in line with other experimental reports $[43,44,50]$. Chloroquine-treated mice survived and were cured.

Body weight loss is another feature of $P$. berghei infected mice. This is resulted from the appetite depressant action on mice, the disturbed metabolic function and hypoglycaemic effect of the parasite [36]. The weight changes caused by all extract treated mice were not significant compared to distilled water treated mice. The difference might be explained by the imbalance of the protective effect of the extract and the cumulative pathologic changes associated with the infection. A similar finding was reported by another experimental study [44].

The anti-malarial activities of plants are due to the presence of bioactive secondary metabolites in the crude plant material. Different secondary metabolites including alkaloids, glycosides, indoles, phenols, tannins, saponins and steroids $[21,48]$ have been reported from the extract of Euphorbia abyssinica. These metabolites have established anti-malarial activities [51]. Their anti-malarial activities could have resulted from single or in synergistic action [52]. The possible anti-malarial activity of the plant might be through anti-oxidation and free radical scavenging, immunomodulatory, intercalation in deoxyribonucleic acid (DNA), inhibition of protein synthesis, interference with enterocytes' invasion, or by any other unknown mechanisms.

\section{Conclusion}

From this study, it can be concluded that the root of Euphorbia abyssinica showed very good 4-day chemosuppressive anti-malarial activity. The plant may contain biologically active principles which are relevant for treatment of malaria. In addition, the extract did not show any sign of toxicity and death at limit dose of $2000 \mathrm{mg} / \mathrm{kg}$. Further phytochemical, toxicological and pharmacological investigations are, therefore, required to evaluate its full anti-malarial potential.

\section{Abbreviations}

ANOVA: analysis of variance; DNA: deoxyribonucleic acid; $I_{50}$ : median inhibitory concentration; $\mathrm{LD}_{50}$ : median lethal dose; MST: mean survival time; $\mathrm{OECD}$ : Organization for Economic Cooperation and Development; RBCs: red blood cells; SEM: standard error of mean; SPSS: statistical package for social sciences; WHO: World Health Organization.

\section{Acknowledgements}

We would like to thank Wollega University for funding this research. We would also like to thank to all individuals who assist in transporting and handling of experimental animals, preparation of their pellets, and facilitating the laboratory procedures.

\section{Authors' contributions}

ABM did the extraction. ABM and SKA administered the extract to experimental animals. GTD examined the blood smears. ABM analysed and interpreted the data. ABM was a major contributor in writing the manuscript. ABM and AGD substantially revised and modified the final draft. All authors read and approved the final manuscript.

\section{Funding}

This study was funded by Wollega University, Ethiopia.

\section{Availability of data and materials}

The datasets used and/or analysed during the current study are available from the corresponding author on reasonable request.

\section{Ethics approval and consent to participate}

Ethical clearance was requested and approved by the ethical committee of College of Health Sciences, Wollega University, Ethiopia.

\section{Consent for publication}

All authors have reviewed and consent for publication of this manuscript.

Competing interests

The authors declare that they have no competing interests. 


\section{Author details}

${ }^{1}$ Department of Pharmacy, College of Medicine and Health Sciences, Bahir Dar University, Bahir Dar, Ethiopia. ${ }^{2}$ Department of Pharmacy, College of Health Sciences, Wachamo University, Hosanna, Ethiopia. ${ }^{3}$ Department of Medical Laboratory Sciences, College of Health Sciences, Wollega University, Nekemte, Ethiopia.

Received: 26 November 2018 Accepted: 22 July 2019

Published online: 30 July 2019

\section{References}

1. Nii-Trebi NI. Emerging and neglected infectious diseases: insights, advances, and challenges. Biomed Res Int. 2017;2017:5245021.

2. Mahmoudi S, Keshavarz H. Efficacy of phase 3 trial of RTS,S/AS01 malaria vaccine: the need for an alternative development plan. Hum Vaccin Immunother. 2017;13:2098-101.

3. WHO. World malaria report. Geneva: World Health Organization; 2018. https://apps.who.int/iris/bitstream/handle/10665/275867/9789241565 653eng.pdf?ua=1. Accessed 20 Mar 2019.

4. Fairhurst RM, Dondorp AM. Artemisinin-resistant Plasmodium falciparum malaria. Microbiol Spectr. 2016;4:1-25.

5. Lu F, Culleton R, Zhang M, Ramaprasad A, von Seidlein L, Zhou H, et al. Emergence of indigenous artemisinin-resistant Plasmodium falciparum in Africa. N Engl J Med. 2017;376:991-3.

6. Bhattacharjee D, Shivaprakash G. Drug resistance in malaria: in a nutshell. J Appl Pharm Sci. 2016;6:137-43.

7. Bazargani YT, Ewen M, de Boer A, Leufkens HGM, Mantel-Teeuwisse AK. Essential medicines are more available than other medicines around the globe. PLoS ONE. 2014;9:0087576.

8. Mahomoodally MF. Traditional medicines in Africa: an appraisal of ten potent African medicinal plants. Evidence-Based Complement Altern. 2013;2013:617459.

9. Willcox ML, Bodeker G. Clinical review traditional herbal medicines for malaria. BMJ. 2004;329:1156-9.

10. Hanboonkunupakarn B, White NJ. The threat of anti-malarial drug resistance. Trop Dis Travel Med Vaccines. 2016;2:1-5.

11. Batista R, Silva Ade JJR, de Oliveira AB. Plant-derived anti-malarial agents: new leads and efficient phytomedicines. Part II. Non-alkaloidal natural products. Molecules. 2009;14:3037-72.

12. Duru CB, Diwe KC, Uwakwe KA, Duru CA, Merenu IA, Iwu AC, et al. Combined orthodox and traditional medicine use among households in Orlu, Imo State, Nigeria: prevalence and determinants. World J Prev Med. 2016:4:5-11.

13. Kahumba J, Rasamiravaka T, Okusa PN, Bakari A, Bizumukama L, Kalonji $J-B$, et al. Traditional African medicine: from ancestral knowledge to a modern integrated future. Science. 2015;350:61-3.

14. Azene BA, Tengnäs B, Kelbesa E, Demissew S, Maundu P. Useful trees and shrubs of Ethiopia: identification, propagation and management for 17 agroclimatic zone. Nairobi: World Agroforestry Centre; 2007. https://www. worldagroforestry.org/usefultrees/frontpages/UsefulTreesEthiopia.pdf. Accessed 15 Sep 2018.

15. IBC. Ethiopia: second country report to the FAO International Technical Conference on plant genetic resources. Addis Ababa: Institute of Biodiversity and Conservation; 1995. http://www.fao.org/fileadmin/templates/ agphome/documents/PGR/SoW1/africa/ETHIOPIA.pdf. Accessed 10 Oct 2018.

16. Alebie G, Urga B, Worku A. Systematic review on traditional medicinal plants used for the treatment of malaria in Ethiopia: trends and perspectives. Malar J. 2017;16:307.

17. Hoareau L, da Silva EJ. Medicinal plants: a re-emerging health aid. Electron J Biotechnol. 1999;2:56-70.

18. Jachak SM, Saklani A. Challenges and opportunities in drug discovery from plant. Curr Sci. 2007;92:1251-7.

19. Kaur K, Jain M, Kaur T, Jain R. Anti-malarials from nature. Bioorg Med Chem. 2009;17:3229-56.

20. Pahlevani AH. Diversity of the genus Euphorbia (Euphorbiaceae) in South West Asia. 2017. https://epub.uni-bayreuth.de/3258/1/ThesisAmirHPahl evaniepub.pdf. Accessed 5 Oct 2018.
21. Tarh JE, Iroegbu CU. In vitro antibacterial activity of extracts of Euphorbia abyssinica (desert candle) stem-bark and latex. J Adv Microbiol. 2017:2:1-13.

22. Abebe W. An overview of Ethiopian traditional medicinal plants used for cancer treatment. European J Med Plants. 2016;14:1-16.

23. Sharaf AEA. Chemical investigation of the Egyptian plant, Euphorbia peplus. Br Vet J. 1949;105:128-35.

24. FDA. Poisonous plant database. Food and Drug Administration of United States of America. https://www.accessdata.fda.gov/scripts/plantox/detai I.cfm?id=23140. Accessed 8 Sep 2018.

25. Giday M, Asfaw Z, Woldu Z. Medicinal plants of the Meinit ethnic group of Ethiopia: an ethnobotanical study. J Ethnopharmacol. 2009;124:513-21.

26. Belayneh A, Asfaw Z, Demissew S, Bussa NF. Medicinal plants potential use by pastoral and agro-pastoral communities in Erer Valley of Babile wereda, Eastern Ethiopia. J Ethnobiol Ethnomed. 2012;8:42.

27. Limenih $Y$, Umer $S$, Woldemariam M. Ethnobotanical study on traditional medicinal plants in Dega Damot woreda, Amhara region, North Ethiopia. Int J Res Pharm Chem. 2015;5:258-73.

28. Chekole G, Asfaw Z, Kelbessa E. Ethnobotanical study of medicinal plants in the environs of Tara Gedam and Amba remnant forests of Libo Kemkem district, Northwest Ethiopia. J Ethnobiol Ethnomed. 2015;11:4.

29. Wubetu M, Abula T, Dejenu G. Ethnopharmacologic survey of medicinal plants used to treat human diseases by traditional medical practitioners in Dega Damot district, Amhara, Northwestern Ethiopia. BMC Res Notes. 2017;10:157.

30. Birhan YS, Kitaw SL, Alemayehu YA, Mengesha NM. Ethnobotanical study of medicinal plants used to treat human diseases in Enarj Enawga district, East Gojjam zone, Amhara region, Ethiopia. J Med Plant Stud. 2018;2:1006.

31. Etana B. Ethnobotanical study of traditional medicinal plants of Goma wereda, Jima zone, Oromia region, Ethiopia. 2010. http://etd.aau.edu.et/ handle/123456789/11339. Accessed 5 Oct 2018.

32. Ajayi EIO, Adeleke MA, Adewumi TY, Adeyemi AA. Anti-plasmodial activities of ethanol extracts of Euphorbia hirta whole plant and Vernonia amygdalina leaves in Plasmodium berghei infected mice. J Taibah Univ Sci. 2017:11:831-5.

33. Kffuri CW, Lopes MA, Ming C, Odonne G, Kinupp VF. Anti-malarial plants used by indigenous people of the Upper Rio Negro in Amazonas, Brazil. J Ethnopharmacol. 2015;178:188-98.

34. Nasir R, Rahiman SF, Hasballah K, Chong W, Talib H, Yam M, et al. Plasmodium berghei ANKA infection in ICR mice as a model of cerebral malaria. Iran J Parasitol. 2012;7:62-74.

35. OECD. Guidelines for the testing of chemicals, acute oral toxicity-upand-down-procedure (UDP). No. 425. Organization for Economic Cooperation and Development; 2008. https://ntp.niehs.nih.gov/iccvam/suppd ocs/feddocs/oecd/oecdtg425.pdf. Accessed 20 Sep 2018.

36. Fidock DA, Rosenthal PJ, Croft SL, Brun R, Nwaka S, Einstein A. Anti-malarial drug discovery: efficacy models for compound screening. Nat Rev Drug Discov. 2004;3:509-20.

37. ILAR. Guide for the care and use of laboratory animals. Washington DC: Institute for Laboratory Animal Research; 2011. https://grants.nih.gov/ grants/olaw/guide-for-the-care-and-use-of-laboratory-animals.pdf. Accessed 5 Sep 2018.

38. Lopez V. Are traditional medicinal plants and ethnobotany still valuable approaches in pharmaceutical research? Bol Latinoam Caribe Plant Med Aromat. 2011;10:3-10.

39. Patwardhan B, Vaidya ADB, Chorghade M. Ayurveda and natural products drug discovery. Curr Sci. 2004;86:789-99.

40. Pawar HA. Natural products as a source of lead to the design of new drugs. Nat Prod Chem Res. 2014;2:2-4.

41. Kassaye KD, Amberbir A, Getachew B, Mussema Y. A historical overview of traditional medicine practices and policy in Ethiopia. Ethiop J Heal Dev. 2006;20:127-34.

42. Krettli AU, Adebayo JO, Krettli LG. Testing of natural products and synthetic molecules aiming at new testing of natural products and synthetic molecules aiming at new anti-malarials. Curr Drug Targets. 2009;10:261-70.

43. Muluye AB, Melese E, Adinew GM. Anti-malarial activity of $80 \%$ methanolic extract of Brassica nigra (L.) Koch. (Brassicaceae) seeds against Plasmodium berghei infection in mice. BMC Complement Altern Med. 2015;15:367. 
44. Birru EM, Geta M, Gurmu AE. Anti-plasmodial activity of Indigofera spicata root extract against Plasmodium berghei infection in mice. Malar J. 2017;16:198.

45. Abdisa T. Review on traditional medicinal plant and its extract effect on tick control in Ethiopia. J Vet Med Res. 2017;4:102

46. Mekbib S, Regnier T, Zeeman C, Korsten L. In vitro anti-microbial assay of some medicinal plants from Ethiopia against plant and food-borne pathogens. University of Pretoria; 2007. http://repository.up.ac.za/dspace/ bitstream/handle/2263/25334/05chapter5.pdf?. Accessed 20 Sep 2018.

47. Fikya FE, Asresb K, Gibbonsc S, Hammodaa H, Badrd J, Umerb S. Phytochemical and anti-microbial investigation of latex from Euphorbia abyssinica Gmel. Nat Prod Commun. 2008:3:1505-8.

48. Mengiste B, Mekuria A, Aleme H, Afera B, Negash G. Treatment of skin disease using ointment of latex of Euphorbia abyssinica medicinal plant on animal model. World Appl Sci J. 2014;32:1913-7.

49. Munoza V, Sauvainb M, Bourdyb G, Callapaa J, Bergeronc S, Rojasa I, et al. A search for natural bioactive compounds in Bolivia through a multidisciplinary approach: Part I. Evaluation of the anti-malarial activity of plants used by the Chacobo Indians. J Ethnopharmacol. 2000;69:127-37.
50. Tesfaye WH, Alamneh EA. In vivo anti-malarial activity of the crude extract and solvent fractions of the leaves of Zehenria scabra (Cucurbitaceae) against Plasmodium berghei in mice. J Med Plant Res. 2014;8:1230-6.

51. Nogueira CR, Lopes LMX. Anti-plasmodial natural products. Molecules. 2011;16:2146-90.

52. Wink M. Modes of action of herbal medicines and plant secondary metabolites. Medicines. 2015:2:251-86.

\section{Publisher's Note}

Springer Nature remains neutral with regard to jurisdictional claims in published maps and institutional affiliations.
Ready to submit your research? Choose BMC and benefit from:

- fast, convenient online submission

- thorough peer review by experienced researchers in your field

- rapid publication on acceptance

- support for research data, including large and complex data types

- gold Open Access which fosters wider collaboration and increased citations

- maximum visibility for your research: over $100 \mathrm{M}$ website views per year

At BMC, research is always in progress.

Learn more biomedcentral.com/submissions 